\title{
POSTMINING DISCHARGE ACTIVE AND PASSIVE TREATMENT COST EVALUATION ${ }^{1}$
}

\author{
T. P. Danehy ${ }^{2}$, G. T. Hilton, C. F. Denholm, S. L. Busler, B. J. Page and M. H. Dunn
}

\begin{abstract}
Current regulatory conditions in Pennsylvania require mine operators responsible for postmining discharges to post a bond or establish an alternative financial mechanism (trust) to provide for costs associated with perpetual treatment. The bond or trust amount is calculated using current and projected operating and capital costs in conjunction with applicable financial assumptions. Though the calculated value of a trust is typically about half the comparable bond amount, the burden borne by mining operators to satisfy either the trust or bond requirements can be significant. Evaluating treatment options and implementing appropriate treatment technology in order to reduce annual treatment costs can lead to substantial reductions in bond requirements or cash outlays needed for trust establishment. Seven post-mining discharge treatment sites that utilized active, passive and hybrid (combination of active and passive) treatment systems were upgraded to utilize only passive technology. The cost evaluation presented illustrates that an additional capital investment of about $\$ 0.2 \mathrm{M}$ reduced the calculated bond and trust amounts by about $\$ 2.2 \mathrm{M}$ and $\$ 1.3 \mathrm{M}$ respectively.
\end{abstract}

Additional Key Words: Chemical Treatment, Trust Funds, Perpetual Treatment, Permitted Post-Mining Discharge

\footnotetext{
${ }^{1}$ Paper was presented at the 2010 National Meeting of the American Society of Mining and Reclamation, Pittsburgh, PA Bridging Reclamation, Science and the Community June 5 - 11, 2010. R.I. Barnhisel (Ed.) Published by ASMR, 3134 Montavesta Rd., Lexington, KY 40502.

2 Timothy P. Danehy, QEP is Senior Project Manager at BioMost, Inc. and works closely with his coauthors G. Tiff Hilton, Mining Eng.; Clifford F. Denholm, Env. Sci.; Shaun L. Busler, GISP; Bryan J. Page, Env. Geo.; Margaret H. Dunn, PG, CPG; BioMost, Inc., 434 Spring Street Ext., Mars, PA 16046

Proceedings America Society of Mining and Reclamation, 2010 pp 138-152

DOI: 10.21000/JASMR10010138
}

http://dx.doi.org//10.21000/JASMR10010138 


\section{$\underline{\text { Introduction }}$}

The goal of this paper is to provide detailed cost information to demonstrate the impact of treatment technology selection on financial assurance mechanism funding requirements as well as illustrate the differences between postmining discharge bonds (Bonds) and alternative financial assurance mechanisms (Trusts). It is assumed that all treatment technology deployed is appropriate and adequate to meet all applicable effluent limits and is properly designed and constructed. It is acknowledged that there are pros and cons with design and implementation any treatment technology for any given discharge.

The data presented in this paper were gathered from attachments to a Consent Order and Agreement (COA) developed in establishing a Trust for seven discharges issuing from

completed surface coal mines in the bituminous coal region in Pennsylvania. Additional information was obtained from quarterly monitoring reports submitted to the Pennsylvania Department of Environmental Protection (PADEP). Though some information is available online, the specific cost and monitoring data is only publically available by review of paper files; therefore, no site locations or specific names are provided in consideration of the privacy of the mine operator (Operator).

The surface mines that were operated through the 1970's into the early 1980's resulted in a total of seven postmining discharges. The Operator deployed various technologies to deal with these discharges including active, passive and hybrid treatment summarized in Table 1. Active treatment consisted of $\mathrm{NaOH}$ additions followed by settling ponds. Passive treatment included vertical flow ponds, settling ponds and aerobic wetlands. Hybrid sites included passive treatment components supplemented with the addition of $\mathrm{NaOH}$.

In order to reduce treatment costs and help insure continued permit compliance, all seven treatment systems were upgraded to varying degrees from 2003 through 2005 to the current configurations summarized in Table 2. Active treatment systems were removed and replaced by passive treatment systems at three of the seven sites (Sites 2, 4 \& 7). Additional passive components were installed at the three hybrid treatment sites (Sites 1, 3,6) to eliminate the use of $\mathrm{NaOH}$. The existing passive treatment site was expanded to reduce labor and maintenance burden. 
Table 1. Treatment System Configurations before Upgrades (Active/Hybrid)

\begin{tabular}{|c|c|}
\hline Site & reatment System Description \\
\hline & h drain $) \rightarrow$ Caustic $\rightarrow 300 \mathrm{sm} \mathrm{SP}-$ \\
\hline Site 2 & $\begin{array}{l}183 \mathrm{~m} \text { collection sys. (sumps and pipes/hoses) } \rightarrow \text { Pump } \rightarrow 490 \mathrm{~m} \text { Pump Line }(34 \mathrm{~m} \\
\text { vertical head) } \rightarrow \text { Liquid Caustic } \rightarrow 370 \mathrm{sm} \mathrm{SP} \rightarrow 370 \mathrm{sm} \mathrm{SP}\end{array}$ \\
\hline Site 3 & $198 \mathrm{~m} \mathrm{CC} \rightarrow 334 \mathrm{sm} \mathrm{SP} \rightarrow 544 \mathrm{t} / 137 \mathrm{~cm} \mathrm{VFP} \rightarrow$ Caustic $\rightarrow 1,100 \mathrm{sm} \mathrm{SP}$ \\
\hline Site 4 & $61 \mathrm{~m} \mathrm{CC} \rightarrow$ Pump $\rightarrow 183 \mathrm{~m}$ Pump Line $(20 \mathrm{~m}$ vertical head $) \rightarrow \mathrm{C}$ \\
\hline Site 5 & $\mathrm{VFP} \rightarrow 316$ \\
\hline & $\mathrm{L} \rightarrow$ \\
\hline Site 7 & $18 \mathrm{~m} \mathrm{CC} \rightarrow \mathrm{Ca}$ \\
\hline \multicolumn{2}{|c|}{$\begin{array}{l}\text { CC - Collection Channel; cm - Cubic Meters Spent Mushroom Compost; SP }- \text { Settling Pond; } \\
\text { sm - Square Meters, T - Metric Ton High Calcium Carbonate Limestone ( } 90 \% \text { CaCO3); VFP } \\
\text { - Vertical Flow Pond; WL - Aerobic Wetland; All dimensions are very } \\
\text { approximate/representative. }\end{array}$} \\
\hline
\end{tabular}

Table 2. Treatment System Configurations after Upgrades (Passive)

\begin{tabular}{|c|c|}
\hline Site & reatment System Description \\
\hline Site 1 & $\begin{array}{l}122 \mathrm{~m} \text { collection sys. (French drain) } \rightarrow 371 \mathrm{sm} \mathrm{SP} \rightarrow 204 \mathrm{sm} \mathrm{WL} \rightarrow 297 \mathrm{sm} \mathrm{WL} \rightarrow \\
907 \mathrm{t} \mathrm{HFLB} \rightarrow 150 \mathrm{sm} \text { Open Limestone Channel }\end{array}$ \\
\hline Site 2 & $650 \mathrm{sm} \mathrm{SP} \rightarrow 997 \mathrm{t} / 535 \mathrm{~cm} \mathrm{VFP} \rightarrow 300 \mathrm{sm} \mathrm{SP} \rightarrow 140 \mathrm{sm} \mathrm{WL} \rightarrow 907 \mathrm{t} \mathrm{HFLB}$ \\
\hline Site 3 & $198 \mathrm{~m} \mathrm{CC} \rightarrow 334 \mathrm{sm} \mathrm{SP} \rightarrow 544 \mathrm{t} / 138 \mathrm{~cm} \mathrm{VFP} \rightarrow 1,110 \mathrm{sm} \mathrm{SP} \rightarrow 363 \mathrm{t} \mathrm{HFLB}$ \\
\hline Site 4 & $\begin{array}{l}61 \mathrm{~m} \mathrm{CC} \rightarrow 167 \mathrm{sm} \mathrm{SP} \rightarrow 635 \mathrm{t} / 46 \mathrm{~cm} \mathrm{VFP} \rightarrow 74 \mathrm{sm} \mathrm{SP} \rightarrow 288 \mathrm{sm} \mathrm{WL} \rightarrow 74 \mathrm{sm} \mathrm{SP} \\
\rightarrow 74 \mathrm{sm} \text { Level Spreader } \rightarrow 140 \mathrm{sm} \mathrm{SP} \rightarrow 544 \mathrm{t} \text { HFLB }\end{array}$ \\
\hline Site 5 & $46 \mathrm{~m} \mathrm{CC} \rightarrow 270 \mathrm{sm} \mathrm{SP} \rightarrow 562 \mathrm{t} / 15 \mathrm{~cm} \mathrm{VFP} \rightarrow 316 \mathrm{sm} \mathrm{SP} \rightarrow 390 \mathrm{sm} \mathrm{SP}$ \\
\hline Site 6 & $76 \mathrm{~m}$ \\
\hline Site 7 & $37 \mathrm{~m}$ collection sys. (French drain) $\rightarrow 272 \mathrm{t} / 153 \mathrm{~cm}$ VFP $\rightarrow 83 \mathrm{sm} \mathrm{SP} \rightarrow 272 \mathrm{t}$ HFLB \\
\hline \multicolumn{2}{|r|}{$\begin{array}{l}\text { CC - Collection Channel; cm - Cubic Meters Spent Mushroom Compost/Wood Chips; HFLB - } \\
\text { Horizontal Flow Limestone Bed; sm - Square Meters, SP - Settling Pond; T - Metric Tons High } \\
\text { Calcium Carbonate Limestone (>90\% CaCO3); VFP - Vertical Flow Pond; WL - Aerobic } \\
\text { Wetland; All dimensions are very approximate/representative. }\end{array}$} \\
\hline
\end{tabular}

\section{Background}

Post-mining discharges from reclaimed surface coal mines may need to be treated to meet applicable effluent limits. If treatment is required, the Operator is required to provide treatment until the untreated discharge meets effluent limit criteria. Discharges treated using conventional (active) systems must comply with the standard effluent limits shown in Table 3. If approved by PADEP, mine operators may choose to convert active treatment systems to passive treatment systems and qualify, in most cases, for waivers of certain effluent limits and comply with the effluent limits set forth in Table 2. Prior to converting all seven sites to fully passive technology, 
the Operator's NPDES permits limits were set at the standard limits shown in Table 1. After the conversion, NPDES permits were reissued to reflect the limits presented in Table 3. It is noted that more stringent effluent limits may be imposed by PADEP in order to maintain "in stream" water quality and/or comply with and an established Total Maximum Daily Load (TMDL).

\section{Effluent Limits}

Table 3. Applicable Effluent Limitations: Pennsylvania Code Title 25 Chapter 87 subchapter 87.102(a) - Group A (Active Treatment).

\begin{tabular}{|c|c|c|c|c|}
\hline $\begin{array}{c}\text { pH } \\
\text { s.u. }\end{array}$ & Alkalinity \& Acidity & $\begin{array}{c}\text { Iron } \\
(\mathbf{m g} / \mathbf{L})\end{array}$ & $\begin{array}{c}\text { Manganese } \\
(\mathbf{m g} / \mathbf{L})\end{array}$ & $\begin{array}{c}\text { Total Suspended Solids } \\
(\mathbf{m g} / \mathbf{L})\end{array}$ \\
\hline $6.0<\mathrm{pH}<9.0$ & Alkalinity > Acidity & 7.0 & 5.0 & 90 \\
\hline
\end{tabular}

Notes: Metals and TSS are instantaneous maximum.

Table 4. Applicable Effluent Limitations (Passive Treatment): Pennsylvania Code Title 25 Chapter 87 subchapter 87.102(e)(3) - Group A with Postmining Pollutional discharge exceptions.

\begin{tabular}{|c|c|}
\hline Alkalinity \& Acidity & $\begin{array}{c}\text { Iron } \\
(\mathbf{m g} / \mathbf{L})\end{array}$ \\
\hline Alkalinity $>$ Acidity & 7.0 (or 90\% reduction if raw Fe is $>70.0 \mathrm{mg} / \mathrm{L})$ \\
\hline
\end{tabular}

Notes: Iron is instantaneous maximum.

Table 5. NPDES Permit Effluent Limitations for Site 1 through Site 7.

\begin{tabular}{|c|c|c|c|}
\hline $\begin{array}{c}\text { pH } \\
\text { S.u. }\end{array}$ & Alkalinity \& Acidity & $\begin{array}{c}\text { Iron } \\
(\mathbf{m g} / \mathbf{L})\end{array}$ & $\begin{array}{c}\text { Total Suspended Solids } \\
(\mathbf{m g} / \mathbf{L})\end{array}$ \\
\hline $6.0<\mathrm{pH}<9.0$ & Alkalinity $>$ Acidity & 7.0 & 90 \\
\hline
\end{tabular}

Note: $90 \%$ reduction of $\mathrm{Fe}$ not applicable due to all discharges typically having $<70.0 \mathrm{mg} / \mathrm{L}$ iron in raw water. Iron and TSS are instantaneous maximum. 


\section{Discharge Characteristics}

Table 6. Representative Raw Discharge Characteristics.

\begin{tabular}{|c|c|c|c|c|c|c|c|c|}
\hline \multirow{2}{*}{$\begin{array}{c}\text { Site } \\
\text { Name }\end{array}$} & \multicolumn{2}{|c|}{ Flow } & \multirow{2}{*}{$\mathrm{pH}$} & \multirow{2}{*}{ Alk } & Acid & Fe & Mn & \multirow{2}{*}{ Al } \\
\cline { 2 - 8 } & Avg & Max. & & & & & & \\
\hline Site 1 & 3.7 & 6.5 & 7.8 & 434 & 26 & 32 & 18 & 0 \\
\hline Site 2 & 2.3 & 6.0 & 4.5 & 0 & 212 & 6 & 24 & 27 \\
\hline Site 3 & 0.6 & 0.8 & 6.1 & 58 & 158 & 10 & 35 & 6 \\
\hline Site 4 & 0.4 & 0.9 & 4.0 & 0 & 117 & 3 & 13 & 15 \\
\hline Site 5 & 0.6 & 0.6 & 3.9 & 0 & 206 & 1 & 26 & 27 \\
\hline Site 6 & 0.1 & 0.4 & 3.8 & 0 & 52 & 1 & 11 & 4 \\
\hline Site 7 & 0.2 & 0.6 & 4.6 & 0 & 216 & 24 & 21 & 24 \\
\hline
\end{tabular}

The above data was compiled from the limited aforementioned available information to provide a reasonable representation of raw water characteristics. Site 1 acidity is calculated from approximate carbonate acidity, actual "hot" acidity is $-275 \mathrm{mg} / \mathrm{L}$ and is more than sufficient to neutralize "mineral acidity" (approximately $91 \mathrm{mg} / \mathrm{L}$ ). Acidity for Sites 4, 6 and 7 are calculated.

\section{$\underline{\text { Bonds \& Trusts }}$}

Operators with post-mining treatment sites must post bonds to insure that sufficient funds are available if they go out of business and essentially turn the treatment liability over to the Commonwealth of Pennsylvania (Commonwealth). PADEP has developed a process to calculate the amount of bond needed to provide perpetual treatment of a postmining discharge. This process entails using the cost modeling program AMDTreat developed as a cooperative effort by the U.S. Office of Surface Mining Reclamation and Enforcement (OSM), PADEP and the West Virginia Department of Environmental Protection. Calculations using AMDTreat presented in this paper were performed using version 4.1c (OSM, 2006). As an alternative to conventional surety or collateral bonds, PADEP has developed a mechanism in which mine operators establish site-specific trusts held by a third party trustee that provide the on-going cash resources needed to operate and maintain treatment systems.

If operator goes out of business and forfeits the bonds posted for a mine site, the bond money is collected by the Commonwealth through the forfeiture process and placed into the state treasury. Because the bond forfeiture and collection process takes a substantial amount of time, 
typically one year, one additional year of treatment costs is built into the calculated bond amount to allow the Commonwealth to recoup expenses incurred after the Operator goes out of business, but before the funds are collected. In addition, because of the more conservative nature of investments made by the Commonwealth, the rate of return for forfeited bond funds held by the Commonwealth is set at $6.00 \%$.

Alternatively, operators may establish trusts that are held by a third party trustee and are specifically designated to cover the long term operation and maintenance of a treatment site. These trusts are typically placed in more aggressive investment portfolios and the PADEP allows net estimated earnings rates up to $8.43 \%$. The estimated trust earnings are based on $80 \%$ invested in stocks earning $11.1 \%, 20 \%$ invested in bonds earning 5.25\% resulting in a weighted gross return of $9.93 \%$ minus trust fees estimated at $1.5 \%$ (Danehy, 2006).

Regardless of the financial mechanism established by the Operator, the PADEP requires a regular review to insure that Bond or Trust is sufficient to cover the actual treatment costs. Bonds are reviewed near the end each permit term, typically every five years, while Trusts are evaluated annually. If the trust or bond is found to be insufficient, the Operator is required to provide additional funds or post more bond, respectively. Alternatively, if actual costs are less than projected, the Operator may have funds or bonds released.

\section{Bond and Trust Calculations}

The PADEP developed Equations 1 - 3 to determine the amount of bond needed to cover a postmining pollutional discharge (Faith, 2007).

The notations below the equations have been modified from the original PADEP equations for clarity of this paper.

The PADEP typically requires the Total Bond and Total Trust amounts to include the Present Value of liability insurance based on liability insurance factor of $0.1 \%$ of the Total Bond or Trust amounts. For the purposes of this paper, however, calculations relating to insurance requirements are not presented. The insurance costs would be treated an additional annual cost and impact the calculations accordingly. 


$$
\begin{gathered}
\mathrm{PV}_{\mathrm{AB}}=\mathrm{A}(1+\mathrm{I})^{\mathrm{PT}} /(\mathrm{RoR}-\mathrm{I})+\mathrm{A}(1+\mathrm{I})^{\mathrm{PT}} \\
\mathrm{PV}_{\mathrm{RBP}}=\mathrm{PV}_{\mathrm{RB}}(1+\mathrm{I})^{\mathrm{PT}} \\
\text { TOTAL BOND }=\mathrm{PV}_{\mathrm{AB}}+\mathrm{PV}_{\mathrm{RBP}}
\end{gathered}
$$

The PADEP also developed an Equations 4 - 6 to determine the amount of a Treatment Trust:

$$
\begin{gathered}
\mathrm{PV}_{\mathrm{B}}=(\mathrm{A} /[\mathrm{E}-\mathrm{I}])+\mathrm{A} \\
\mathrm{PV}_{\mathrm{T}}=\mathrm{PV}_{\mathrm{B}}(\mathrm{VI}) \\
\text { TOTAL TRUST }=\mathrm{PV}_{\mathrm{T}}+\mathrm{PV}_{\mathrm{RT}}
\end{gathered}
$$

Where:

$$
\begin{aligned}
& \text { A } \quad=\text { Annual Treatment Cost } \\
& \mathrm{E}=\text { Annual Earnings Rate }(20 \% \text { Bond, } 80 \% \text { Stock }=8.43 \%)-\text { Trust } \\
& \text { I } \quad=\text { Inflation Rate }(3.10 \%)-(\text { Bond and Trust }) \\
& \text { PT }=\text { Permit Term }(5 \text { years })-\text { Bond } \\
& \mathrm{PV}_{\mathrm{AB}}=\text { Present Value Annual Costs }- \text { Bond } \\
& \mathrm{PV}_{\mathrm{B}}=\text { Present Value (Annual Costs) Primary Basis Valuation }- \text { Trust } \\
& \mathrm{PV}_{\mathrm{RB}}=\text { Present Value Recapitalization Cost }- \text { Bond (From AMDTreat) } \\
& \mathrm{PV}_{\mathrm{RBP}}=\text { Present Value Recapitalization Cost at End of Permit Term }- \text { Bond } \\
& \mathrm{PV}_{\mathrm{RT}}=\text { Present Value Recapitalization Cost }- \text { Trust (From AMDTreat) } \\
& \mathrm{PV}_{\mathrm{T}} \quad=\text { Present Value (Annual Costs) Primary Target Valuation - Trust } \\
& \text { RoR = Rate of Return }(6.00 \%)-\text { Bond } \\
& \text { VI }=\text { Volatility Index (1.16) }- \text { Trust }
\end{aligned}
$$

$\mathrm{PV}_{\mathrm{B}}$ is the minimum calculated amount of the trust (Basis valuation), if the trust falls below this amount the PADEP requires the Operator to add funds to the trust. $\mathrm{PV}_{\mathrm{T}}$ is the Target value of the trust (basis multiplied by a volatility factor). When the actual cash value of the trust is above the calculated $\mathrm{PV}_{\mathrm{T}}$ for a given year, the operator will be reimbursed out of the trust for the actual annual cost for that year.

\section{$\underline{\text { Cost Data }}$}

\section{$\underline{\text { Capital and Annual Costs }}$}

Actual data for treatment costs prior to the system upgrades was not available, therefore, the data shown in Table 5 represent theoretical values estimated using the cost modeling tool 
AMDTreat. Many costs for the Active treatment systems were developed using default values provided in AMDTtreat v4.1c. Some default costs were modified based on specific details available in public documents for the sites. The total capital costs (estimated costs to build complete new system) are used to estimate the annual maintenance cost.

Table 7. Representative Calculated Active Treatment Costs.

\begin{tabular}{|c|c|c|c|c|c|c|c|}
\hline Site & Capital & \multicolumn{6}{|c|}{ Annual Costs } \\
\cline { 5 - 8 } Name & Cost & Samp. & Labor & Maint. & Chem. & Sludge & Total \\
\hline Site 1 & $\$ 12,199$ & $\$ 643$ & $\$ 7,280$ & $\$ 495$ & $\$ 1,899$ & $\$ 1,882$ & $\$ 12,199$ \\
\hline Site 2 & $\$ 27,887$ & $\$ 643$ & $\$ 10,010$ & $\$ 976$ & $\$ 9,448$ & $\$ 1,309$ & $\$ 22,386$ \\
\hline Site 3 & $\$ 14,137$ & $\$ 643$ & $\$ 5,460$ & $\$ 495$ & $\$ 1,760$ & $\$ 293$ & $\$ 8,651$ \\
\hline Site 4 & $\$ 7,887$ & $\$ 643$ & $\$ 6,370$ & $\$ 276$ & $\$ 869$ & $\$ 119$ & $\$ 8,277$ \\
\hline Site 5 & $\$ 15,387$ & $\$ 643$ & $\$ 10,010$ & $\$ 539$ & $\$ 2,550$ & $\$ 345$ & $\$ 14,087$ \\
\hline Site 6 & $\$ 11,637$ & $\$ 643$ & $\$ 3,640$ & $\$ 407$ & $\$ 129$ & $\$ 20$ & $\$ 4,839$ \\
\hline Site 7 & $\$ 12,887$ & $\$ 643$ & $\$ 3,640$ & $\$ 451$ & $\$ 802$ & $\$ 132$ & $\$ 5,668$ \\
\hline Total & $\mathbf{\$ 1 0 2 , 0 2 1}$ & $\mathbf{\$ 4 , 5 0 1}$ & $\mathbf{\$ 4 6 , 4 1 0}$ & $\mathbf{\$ 3 , 6 3 9}$ & $\mathbf{\$ 1 7 , 4 5 7}$ & $\mathbf{\$ 4 , 1 0 0}$ & $\mathbf{\$ 7 6 , 1 0 7}$ \\
\hline
\end{tabular}

Capital costs include components specific to the treatment system (i.e. ponds, chemical storage tanks and delivery systems, etc.); For the purposes of this paper, other costs such as roads, various ancillary site improvements and engineering that would be common to both passive and active treatment that could be very significant depending on site conditions, access, etc. are not included. Site 2 and Site 5 had pumping operations prior to the passive upgrade, for cost comparison purposes, it is assumed that the existing active systems could have been constructed to avoid pumping and therefore the capital and annual costs associated with pumping are not included in the active treatment costs. Annual chemical consumption is based on the representative raw water characteristics (Table 6). For simplicity, any treatment provided by existing passive components (Sites 3,5 and 6) has been disregarded. Capital costs for a caustic system have been added to Site 5 .

\section{Active Cost Assumptions used in AMDTreat:}

Capital - Caustic: $100 \%$ mixing efficiency; tank cost based on $\$ 2.50 /$ gal and sized to be filled twice/year based on projected chemical consumption (rounded up to nearest 500 gal), steel 
double-wall 2,500 gal tank could cost is about \$6,300 (Brookville Tank, personal communication 03/18/2010); 2 valves \$50/each; 20' feeder \$0.35/ft; Installation 8 hours at \$35/hr.

Capital - Ancillary - Ponds: Typical AMDTreat minimum \$5,000/pond

Annual - Sampling: Established cost \$643/site/year (quarterly 3 points/site).

Annual - Labor: 2 visits per week at \$35/hour (hours vary by site)

Annual - Maintenance: $3.5 \%$ of Capital Cost

Annual - Chemical: $99 \%$ pure $20 \% \mathrm{NaOH} ; 100 \%$ efficient; $\$ 0.70 /$ gal

Annual - Sludge Removal \$0.06/gallon; 5\% solids; 8.33 lbs/gal

Collection system for Site 1 was not included in capital cost.

Actual costs presented in the PADEP reviewed and approved attachments of the COA are presented in Table 8. The Capital Costs represent the estimate to construct an entirely new passive treatment system. The Operator utilized existing treatment structures as feasible and the actual upgrade cost could roughly be estimated to be about $2 / 3$ of the total Capital Cost shown in Table 8 (a detailed analysis of actual upgrade cost was not conducted). Due to the unique nature of many of the treatment components and lack of similarity to the available modules in AMDTreat, a detailed specific cost estimate for each passive treatment component was submitted to and reviewed by PADEP in place of using AMDTreat to estimate capital costs.

Table 8. Representative Calculated Passive Treatment Costs.

\begin{tabular}{|c|c|c|c|c|c|}
\hline \multirow{2}{*}{$\begin{array}{c}\text { Site } \\
\text { Name }\end{array}$} & \multirow{2}{*}{ Capital Cost } & \multicolumn{4}{|c|}{ Annual Costs } \\
\cline { 3 - 6 } & & Samp. & Labor & Maint. & Total \\
\hline Site 1 & $\$ 30,744$ & $\$ 643$ & $\$ 1,029$ & $\$ 507$ & $\$ 2,179$ \\
\hline Site 2 & $\$ 86,924$ & $\$ 643$ & $\$ 1,029$ & $\$ 1,434$ & $\$ 3,106$ \\
\hline Site 3 & $\$ 43,362$ & $\$ 643$ & $\$ 1,029$ & $\$ 715$ & $\$ 2,387$ \\
\hline Site 4 & $\$ 56,913$ & $\$ 643$ & $\$ 1,029$ & $\$ 939$ & $\$ 2,611$ \\
\hline Site 5 & $\$ 24,791$ & $\$ 643$ & $\$ 1,029$ & $\$ 409$ & $\$ 2,081$ \\
\hline Site 6 & $\$ 20,795$ & $\$ 643$ & $\$ 1,029$ & $\$ 343$ & $\$ 2,015$ \\
\hline Site 7 & $\$ 35,957$ & $\$ 643$ & $\$ 1,029$ & $\$ 593$ & $\$ 2,265$ \\
\hline Total & $\mathbf{\$ 2 9 9 , 4 8 6}$ & $\mathbf{\$ 4 , 5 0 1}$ & $\mathbf{\$ 7 , 2 0 3}$ & $\mathbf{\$ 4 , 9 4 0}$ & $\mathbf{\$ 1 6 , 6 4 4}$ \\
\hline
\end{tabular}




\section{Passive Cost Assumptions used:}

Capital - Detailed cost estimates for constructing "new" systems were reviewed and approved by PADEP (the level of detail provided would exceed the scope of this paper)

Annual - Sampling: Established cost at \$643/site/year (3 points/site/quarter)

Annual - Labor: 1 visit/site/month (all seven sites in about 1.5 days)

Annual - Maintenance: $1.65 \%$ of Capital Cost $[1.00 \%$ "typical" plus $0.65 \%$ "contingency factor" that includes site-specific intermittent maintenance (i.e. sludge removal from SPs and WLs), etc.]

\section{$\underline{\text { Recapitalization Costs }}$}

The Recapitalization Cost tool in AMDTreat requires that specific cost data and life expectancy be entered for all the components of a treatment system where periodic and substantial costs will be incurred. These "recap" costs include replacing motors, pumps, valves, silos, etc. for active treatment systems and the cost to remove sludge from aerobic wetlands and replace treatment media in Anoxic Limestone Drains, Vertical Flow Ponds, etc for passive systems (please note that sludge removal for passive sites is included the annual maintenance factor).

Depending on the complexity of the treatment system, various components may have different life expectancies (i.e. a pump may be expected to last 5 years while the treatment media in a vertical flow pond may be designed to last $15-25$ years). The total recapitalization costs in today's dollars for both the active and passive scenarios are presented in Table 7. The Present Value of the recapitalization costs were calculated using the Recapitalization Cost tool in AMDTreat and are presented in Table 8. The total calculation period (total system life span) is set at the default value of 75 years because PADEP studies have shown that calculating present value of recapitalization costs beyond 75 years will have a relatively small impact on the overall cost estimate (OSM, 2006).

\section{Recapitalization Cost Assumptions:}

Active - Replace Storage Tank, valves and feeder lines every 20 years.

Passive - Complete replacement of treatment media in VFPs and HFLBs; Other minor related work (limited pipe replacement, revegetation, etc.) every 15 years. 
Sites 3, 5 and 6 include additional recap event in year 5 with the subsequent recap occurring in year 15 (i.e. rebuilt year 5 and 15 then 30, 45 etc., while Sites 1, 2, 4 and 7 are rebuilt in year 15, 30,45 etc.)

Table 9. Calculated Recapitalization Costs - Active and Passive.

\begin{tabular}{|c|c|c|}
\hline \multirow{2}{*}{ Site Name } & \multicolumn{2}{|c|}{ Recapitalization Cost (Today's Dollars) } \\
\cline { 2 - 3 } & Active & Passive \\
\hline Site 1 & $\$ 4,137$ & $\$ 17,048$ \\
\hline Site 2 & $\$ 17,887$ & $\$ 47,986$ \\
\hline Site 3 & $\$ 4,137$ & $\$ 20,292$ \\
\hline Site 4 & $\$ 2,887$ & $\$ 26,922$ \\
\hline Site 5 & $\$ 5,387$ & $\$ 13,509$ \\
\hline Site 6 & $\$ 1,637$ & $\$ 9,893$ \\
\hline Site 7 & $\$ 2,887$ & $\$ 16,304$ \\
\hline Total & $\mathbf{\$ 3 8 , 9 5 9}$ & $\mathbf{\$ 1 5 1 , 9 5 4}$ \\
\hline
\end{tabular}

Table 10. Present Value Recapitalization Costs from AMDTreat for Bonds and Trusts - Active and Passive.

\begin{tabular}{|c|c|c|c|c|c|c|}
\hline \multirow{3}{*}{ Site Name } & \multicolumn{6}{|c|}{ Present Value Recapitalization } \\
\hline & \multicolumn{3}{|c|}{ Active } & \multicolumn{3}{|c|}{ Passive } \\
\hline & $\begin{array}{c}\mathrm{PV}_{\mathrm{RB}} \\
\text { (BOND) }\end{array}$ & $\begin{array}{l}\mathrm{PV}_{\mathrm{RBP}} \\
(\mathrm{BOND})\end{array}$ & $\begin{array}{c}\mathrm{PV}_{\mathrm{RT}} \\
\text { (TRUST) }\end{array}$ & $\begin{array}{l}\mathrm{PV}_{\mathrm{RB}} \\
\text { (BOND) }\end{array}$ & $\begin{array}{l}\mathrm{PV}_{\mathrm{RBP}} \\
\text { (BOND) }\end{array}$ & $\begin{array}{c}\mathrm{PV}_{\mathrm{RT}} \\
\text { (TRUST) }\end{array}$ \\
\hline Site 1 & $\$ 4,523$ & $\$ 5,269$ & $\$ 2,262$ & $\$ 28,911$ & $\$ 33,679$ & $\$ 14,744$ \\
\hline Site 2 & $\$ 19,554$ & $\$ 22,779$ & $\$ 9,676$ & $\$ 82,924$ & $\$ 96,599$ & $\$ 41,500$ \\
\hline Site 3 & $\$ 4,523$ & $\$ 5,269$ & $\$ 1,852$ & $\$ 34,413$ & $\$ 40,088$ & $\$ 17,549$ \\
\hline Site 4 & $\$ 3,156$ & $\$ 3,676$ & $\$ 1,578$ & $\$ 45,657$ & $\$ 53,186$ & $\$ 23,283$ \\
\hline Site 5 & $\$ 5,889$ & $\$ 6,860$ & $\$ 2,945$ & $\$ 22,910$ & $\$ 26,688$ & $\$ 11,683$ \\
\hline Site 6 & $\$ 1,790$ & $\$ 2,085$ & $\$ 895$ & $\$ 16,777$ & $\$ 19,544$ & $\$ 8,556$ \\
\hline Site 7 & $\$ 3,156$ & $\$ 3,676$ & $\$ 1,578$ & $\$ 27,650$ & $\$ 32,210$ & $\$ 14,100$ \\
\hline Total & $\$ 42,591$ & $\$ 49,614$ & $\$ 20,786$ & $\$ 259,242$ & $\$ 301,994$ & $\$ 131,415$ \\
\hline
\end{tabular}


PVs calculated using 3.1\% inflation and 6.0\% rate of return for bonds and $8.43 \%$ earnings rate for trusts (Mario Carrello, personal communication, 11/02/2009). $\mathrm{PV}_{\mathrm{RBP}}$ is calculated using equation 2 .

\section{$\underline{\text { Annual Cost Present Value }}$}

Annual costs are used with Equation 1 and Equations 4 and 5 to calculate the present value of annual costs for bonds and trusts, respectively.

Table 11. Present Value Annual Costs for Bonds and Trusts - Active and Passive

\begin{tabular}{|c|c|c|c|c|c|c|}
\hline \multirow{3}{*}{ Site Name } & \multicolumn{6}{|c|}{ Present Value Annual Costs } \\
\hline & \multicolumn{3}{|c|}{ Active } & \multicolumn{3}{|c|}{ Passive } \\
\hline & $\begin{array}{c}\mathrm{PV}_{\mathrm{AB}} \\
(\mathrm{BOND})\end{array}$ & $\begin{array}{c}\mathrm{PV}_{\mathrm{B}} \\
\text { (TRUST) }\end{array}$ & $\begin{array}{c}\mathrm{PV}_{\mathrm{T}} \\
\text { (TRUST) }\end{array}$ & $\begin{array}{c}\mathrm{PV}_{\mathrm{AB}} \\
(\mathrm{BOND})\end{array}$ & $\begin{array}{c}\mathrm{PV}_{\mathrm{B}} \\
(\mathrm{TRUST})\end{array}$ & $\begin{array}{c}\mathrm{PV}_{\mathrm{T}} \\
(\mathrm{TRUST})\end{array}$ \\
\hline Site 1 & $\$ 504,237$ & $\$ 241,073$ & $\$ 279,645$ & $\$ 90,067$ & $\$ 43,061$ & $\$ 49,951$ \\
\hline Site 2 & $\$ 925,310$ & $\$ 442,386$ & $\$ 513,168$ & $\$ 128,384$ & $\$ 61,380$ & $\$ 71,201$ \\
\hline Site 3 & $\$ 357,583$ & $\$ 170,959$ & $\$ 198,312$ & $\$ 98,665$ & $\$ 47,171$ & $\$ 54,719$ \\
\hline Site 4 & $\$ 342,124$ & $\$ 163,568$ & $\$ 189,739$ & $\$ 107,924$ & $\$ 51,598$ & $\$ 59,854$ \\
\hline Site 5 & $\$ 582,276$ & $\$ 278,383$ & $\$ 322,925$ & $\$ 86,017$ & $\$ 41,124$ & $\$ 47,704$ \\
\hline Site 6 & $\$ 200,017$ & $\$ 95,627$ & $\$ 110,927$ & $\$ 83,289$ & $\$ 39,820$ & $\$ 46,191$ \\
\hline Site 7 & $\$ 234283$ & $\$ 112,009$ & $\$ 129,931$ & $\$ 93,622$ & $\$ 44,760$ & $\$ 51,922$ \\
\hline Total & $\$ 3,145,830$ & $\$ 1,504,005$ & $\$ 1,744,647$ & $\$ 687,968$ & $\$ 328,914$ & $\$ 381,542$ \\
\hline
\end{tabular}

\section{Total Bond and Trust Amounts}

Equation 3 and Equation 6 are used to calculate the total bond and trust amounts, respectively. 
Table 12. Total Bond and Total Trust Amounts for both Active and Passive Systems.

\begin{tabular}{|c|c|c|c|c|}
\hline \multirow{2}{*}{ Site Name } & \multicolumn{3}{|c|}{ Total Bond and Total Trust } \\
\cline { 2 - 5 } & Total Bond & Total Trust & Total Bond & Total Trust \\
\cline { 2 - 5 } & & & & \\
\hline Site 1 & $\$ 509,506$ & $\$ 281,907$ & $\$ 123,746$ & $\$ 64,695$ \\
\hline Site 2 & $\$ 948,089$ & $\$ 522,844$ & $\$ 224,984$ & $\$ 112,701$ \\
\hline Site 3 & $\$ 362,852$ & $\$ 200,164$ & $\$ 138,753$ & $\$ 72,268$ \\
\hline Site 4 & $\$ 345,801$ & $\$ 191,317$ & $\$ 161,110$ & $\$ 83,137$ \\
\hline Site 5 & $\$ 589,137$ & $\$ 325,870$ & $\$ 112,705$ & $\$ 59,387$ \\
\hline Site 6 & $\$ 202,102$ & $\$ 111,822$ & $\$ 102,832$ & $\$ 54,747$ \\
\hline Site 7 & $\$ 237,959$ & $\$ 131,509$ & $\$ 125,832$ & $\$ 66,022$ \\
\hline Total & $\$ \mathbf{3 , 1 9 5 , 4 4 6}$ & $\mathbf{\$ 1 , 7 6 5 , 4 3 3}$ & $\mathbf{\$ 9 8 9 , 9 6 2}$ & $\$ \mathbf{5 1 2 , 9 5 7}$ \\
\hline
\end{tabular}

\section{$\underline{\text { Discussion }}$}

$\underline{\text { Passive vs. Active }}$

Capital. The total capital costs for active treatment is significantly less than passive for all sites. As shown in Tables 7 and Table 8, the overall cost to install passive treatment systems is almost three times as much as the comparable active treatment system. Deploying passive treatment instead of active treatment required an extra initial investment of roughly $\$ 0.2 \mathrm{M}$.

Annual Maintenance. The calculated capital costs are typically used to estimate the annual maintenance at $3.5 \%$ for active treatment (OSM, 2006) systems and 1.0\% for passive treatment systems (Danehy, 2006). The typical estimated annual maintenance cost for passive systems can also be calculated for a given system using a weighted basis for the type of components installed, using data presented in the Final Recommendations of the Long Term Operation, Maintenance and Replacement Workgroup (PADEP, 2003). As previously noted, a "contingency factor" of $0.65 \%$ was added to the typical $1.00 \%$ to yield a maintenance factor of $1.65 \%$ for all seven sites.

Recapitalization. The larger capital investment need to install passive treatment systems is also reflected in the recapitalization costs, or cost to rebuild certain major components, as shown in Table 9 where the active "recap" amount is about 1/4 the passive amount. 
Annual. The biggest difference between passive and active treatment is the annual cost. Active treatment sites are typically inspected 2-3 times per week, while passive systems are inspected 12 times per month. In addition, the amount of time spent at an active treatment system is typically longer due to the nature of the work, such as adding chemical, adjusting chemical feed rates, etc. (Danehy, 2006). As shown in Tables 7 and 8, the total annual cost for the active systems is $\$ 76,107$ compared to $\$ 16,644$ for the passive systems, resulting in a cost difference of about five times higher for active than passive.

Total Bond and Trust Amount. As observed in Table 12, the total bond and trust amounts for active treatment systems are over three times higher than the relative passive system, a difference of about $\$ 2.2 \mathrm{M}$ and $\$ 1.2 \mathrm{M}$, respectively.

$\underline{\text { Bond vs. Trust }}$

Annual Present Value. Due to the more conservative financial assumptions used with bond calculations, $6.00 \%$ rate of return as compared to $8.43 \%$ used with trust calculations, the present value of annual costs for bonds is considerably higher than for trusts by a factor about two. The annual cost for active systems from Table 7 is $\$ 76,107$ and the present value bonds and trusts from Table 11 is $\$ 3,145,830$ (41 times the calculated annual amount) and \$1,744,647 (23 times the calculated annual amount), respectively.

General. The bond and trust calculations show that the PADEP has structured the funding of postmining discharges so that the total amount of bond needed is almost always higher than the calculated trust amount. As shown in Table 12, the total bond for active is about 1.8 times more than the trust amount and the bond is for passive is more than 1.9 times higher than the relative trust amount. This may not always be the case however, if a lower or more conservative earnings rate "E" is used for trust calculations. As an illustration, if the $6 \%$ rate of return shown for the bond calculations is used for the trust earnings rate, the calculated trust amount would be much more similar to the calculated bond amount (within about 5\%).

\section{Conclusions}

The total calculated bond is typically about 2 times more than the relative calculated trust amount. Coupled with the fact that operators may be reimbursed for their on-going expenses from the earnings of the trust, it appears to make sound financial sense to establish trusts for postmining discharges in place of conventional bonds. 
Though the capital and "recap" costs are significantly higher for passive systems compared to active treatment systems the annual costs for active treatment systems are shown to be five times higher than the passive treatment system equivalent. These higher active annual costs result in total bond and trust financial requirements over three times greater than the relative passive systems.

Based on the data presented, the estimated additional $\$ 0.2 \mathrm{M}$ investment to switch existing treatment systems to entirely passive treatment saved the Operator approximately $\$ 1.3 \mathrm{M}$ in cash when funding a trust with a net realized savings of about $\$ 1.1 \mathrm{M}$.

\section{$\underline{\text { Literature Cited }}$}

Danehy, T.P., T. Hilton, C. Denholm, S. Busler, M. Dunn. 2006. Funding Requirements for Long-Term Post-Mining Discharge Treatment. Proceedings America Society of Mining and Reclamation, 2007 pp 166-183. http://dx.doi.org/10.21000/JASMR07010166.

Faith, Samuel. 2007. Treatment Bond/Trust Calculator. Pennsylvania Department of Environmental Protection, Office of Mineral Resource Management.

Pennsylvania Department of Environmental Protection (PADEP). 2003. Final Recommendations of the Long Term Operation, Maintenance and Replacement Workgroup. http://www.amrclearinghouse.org/Sub/AMDtreatment/OMRworkgroup.pdf

U.S. Department of Interior, Office of Surface Mining Reclamation and Enforcement (OSM). 2006. AMDTreat V4.1c. http://amd.osmre.gov. 